\title{
RESEARCH PERCEIVING ON POSTER AS COMMUNICATION MEDIA, PERCEIVING OF COLLEGE STUDENTS AT SCHOOL OF BUSINESS \& MANAGEMENT \\ IN SWITZERLAND (WESTERN CULTURE) VS INDONESIA (EASTERN CULTURE)
}

Herry Hudrasyah, Institute of Technology Bandung, Indonesia Hartono Yarmanto, Institute of Technology Bandung, Indonesia Subiakto Soekarno, Institute of Technology Bandung, Indonesia

\begin{abstract}
Picture within the advertisement has a role to communicate meanings which are delivered by the marketer to the customers. The problem here is whether customers have good understanding on the picture or not.

This Research has a limitation which is only compare the difference in perception for the posters between college students of Management \& Business in Switzerland and Indonesia. Those two countries are chosen because of the big difference culture and behavior in "the Hofstede"country scores. The subjects of this research are bachelor college students who take major in management from two different top universities in two different countries.

The primary data for the research are collected by using questionnaire which contains "Likert" questions in order to measure the rate of understanding and the perception of the subjects for two different posters (made by Indonesian poster designers and Switzerland poster designers), they are in four different types of category poster for human daily life \#1. WWF Ecological Campaign, \#2. Dairy Product, \#3. Birth Control Product, \#4.Tourism Campaign, which are published also in two different locations, Indonesia and Switzerland areas. These questions can also indicate the respondent's degree of satisfaction and which of the pictures that is preferable by analyzing the Likert answers with graphs mean and T-Test analysis.
\end{abstract}

In conclusion, they know the connection between culture and the communication process of an advertisement and how necessary a marketer to learn intercultural competence.

References Available Upon Request 